\title{
СОЦІОЛОГІЧНА РЕФЛЕКСІЯ: ПОШУК ЦІННІСНО-РАЦІОНАЛЬНОЇ ПАРАДИГМИ НАУКОВОГО ПІЗНАННЯ СУЧАСНОСТІ
}

\author{
А.С. Лобанова
}

\section{1 Вступ}

Сучасний світ постійно ускладнюється, оскільки невпинно розвивається людський розум, що сприяє збільшенню обсягу інформації, зростанню мереж соціальних зв'язків. Як не дивно, разом з цим не зменшується, а збільшується і кількість запитань, на які вчені не можуть дати вичерпних однозначних відповідей. Що необхідно зробити, аби подолати соціальну нерівність у сучасному світі? Як зберегти людство від соціальних та природних катастроф? Яким чином призупинити розповсюдження небезпечних епідемій? Як знайти спільну мову між різними народами? Як загальмувати негативні наслідки поширення віртуальних практик життєдіяльності? Як сформувати гуманістичні відносини між прибічниками різних релігійних доктрин?

Відповіді на ці запитання лежать у площини, насамперед, соціологічної науки, вік і досвід якої досить переконливий - майже два 3 половиною століття - для того, щоб наблизитися до розуміння сутності як глобальних, так і локальних (регіональних, національних) проблем. Розуміючи свою відповідальність за пряму причетність до пояснення соціальних феноменів, соціологи упродовж усієї історії становлення та розвитку соціології рефлексують з приводу розробки єдиної методологічної бази для інтерпретації буденності соціальних суб'єктів, соціальної поведінки різного роду угрупувань, життєдіяльності соціумів.

Актуальні проблеми духовності 
Ретроспектива формування соціологічного знання свідчить про те, що традицією європейської соціології $є$ розробка теорій, американської- акцентуація на емпіричні дослідження. У радянській та вітчизняній соціології, на жаль, своєї традиції не склалося. Доля першої формувалася під впливом виключно марксистсько-ленінської ідеології, яка грунтувалася на соціально-історичному детермінізмі. Як зазначає відомий український соціолог В. Танчер, радянська соціологія мала так званий «прикладний синдром», оскільки обслуговувала «науковий комунізм», закони якого «втілювали, насамперед, соціальнополітичні установки, видавали бажане за дійсне» і «поза увагою залишалися такі важливі цілі соціологічного аналізу, як соціальна активність, особистісні, соціальні конфлікти та зміни, інтроспективна мотивація, екзистенціальні й феноменологічні аспекти діяльності індивіда, гуманізаторська соціально-критична функція соціології» [10, с. 26]. Українська соціологія ${ }^{1}$ у минулому столітті теж «не піднялася вище прикладного обслуговування ідеологічних завдань» (В. Танчер) і знаходилася у постійному пошуку своєї ніші в світовій соціологічній думці, або копіюючи західні підходи, або критикуючи їх. Звісно, останніми роками відбулися суттєві зміни у розвитку вітчизняної соціології, сформувалася сучасна українська соціологічна школа, в межах якої плідно працюють і теоретики, акцентуючи наукову увагу на пошуку ціннісно-раціональної парадигми соціологічного пізнання, і практики, прагнучи з'ясувати детермінанти та тенденції трансформаційних процесів.

\section{2 Чи існує криза соціології?}

Незважаючи на активний науковий дискурс, соціологи так і не виробили єдиного парадигмального статусу науки і сучасне соціологічне знання грунтується на декількох базових парадигмах. Як зазначає відомий російський соціолог Г. Осіпов, основними соціологічними парадигмами є наступні: соціальних фактів, соціальних дефініцій, соціальної поведінки, соціально-історичного детермінізму, які, в свою чергу, інтерпретуються такими теоріями: перша-структурно-функціональною, системною і конфліктною; друга - соціальної дії, символічного інтеракціонізму, етнометодологією, феноменологією; третя - соціаль-

\footnotetext{
${ }^{1}$ Ми поділяємо думку В.Танчера про правомірність використання терміну «українська соціологія» для визначення меж і змісту національного надбання в контексті загального розвитку соціологічної науки.
} 
ного біхевіоризму, теорією соціального обміну, біхевіористською соціологією; четверта - детермінізмом, соціальним історизмом $[8$, с. $72-73$, 109].

Польський соціолог П.Штомпка, аналізуючи становлення та розвиток соціології, виокремлює позитивістську (засновник О. Конт) та антипозитивістську або гуманістичну (засновник М. Вебер) її парадигми. Першій науковій моделі, на його думку, відповідало декілька характерних принципів: обмеження наукового пізнання фактами безпосереднього спостереження і чуттєвого сприйняття з відмовою від міркувань стосовно сутності, квінтесенції, фундаментальних механізмів явищ; узагальнення шляхом індукції, збирання якомога більше фактів з їх наступною класифікацією за ознаками подібності; зведення наукових законів до простих положень про взаємозв'язок між фактами, які з'ясовано під час спостережень; пряме розумове конструювання на основі наукових законів прогностичних моделей майбутніх явищ і нарешті, практичні рекомендації запобігання небажаних або виклику бажаних явищ. Гуманістична парадигма не «обмежується поверховими фактами, що підлягають спостереженню та чуттєвому сприйняттю», вона «сприяє прагненню зрозуміти та стлумачити соціальні явища, засновується на принципах герменевтики, інтерпретаційна, входить до системи культурної антропології, і пануючим у її прибічників, як підкреслює П.Штомпка, $-\epsilon$ «переконання у частковій індетермінації (непояснюваності конкретними причинами) явищ соціального життя, i безпосередньому, заснованому на рефлексії впливі соціальних знань на суспільство» $[13$, с. 18,23$]$.

Відсутність одностайного визнання з боку світового соціологічного співтовариства якоїсь однієї парадигми як базової дає підстави багатьом вченим стверджувати про кризу сучасної соціологічної науки. Так, відомий російський соціолог В.Култигін, зазначає, що процеси ускладнення диференціації соціологічної теорії «часом набувають характеру драми: представники однієї галузі не тільки не знають, але й не розуміють, що роблять їх колеги з іншої галузі соціологічного знання» [5, с. 10].

Французький соціолог Шарль-Анрі Кюен, аналізуючи стан сучасної соціології, виокремлює дві її основні тенденції: занепадання загальної теорії та розрив між мікро- та макрорівнями аналізу [6, с. 17]. Заступник директора Інституту соціології НАН України Є.Головаха вважає, що «криза соціології торкається перш за все її теоретичних основ: можливості вирішувати питання обгрунтованості соціологічних теорій і акумуляції соціологічного знання, збереження його специфі- 
ки в умовах зростаючого взаємопроникнення та інтеграції наук про людину» $[3$, с. 7$]$.

Вважаю, що з наведеними поглядами можна було б погодитися, якби не розуміння того, що і суспільне життя, і суб'єктивна реальність, будучи мінливими і рухомими у просторі і часі, потребують інтенсифікації соціального пізнання. Невипадково соціологи-професіонали знаходяться у стані постійної рефлексії, пошуку ціннісно-раціональної інтерпретації нових реалій, переосмислюючи традиційні наукові підходи, синтезуючи їх з інноваційними соціологічними теоріями, оскільки неможливо нові соціальні зміни вкласти у «прокрустове ложе» учорашніх теорій.

У соціологічному співтоваристві наявно простежується мисленнєве суперництво у сфері продукування універсального соціологічного підходу до інтерпретації сучасних реалій. Переконана, що цей процес буде достатньо тривалим, оскільки неосяжним є розвиток людського розуму. I навряд чи прибічники однієї парадигми поступляться у своєму тлумаченні реальності апологетам іншої, адже це означатиме вичерпаність соціологічного дискурсу. Отже поліпарадигмальність соціології (вік її ще відносно молодий) свідчить не про ІІЇ кризу, а, навпаки, про iï креативний саморозвиток, який носить діалектичний характер ${ }^{2}$. I $€$ сподівання про можливість конвергенції тезаурусів соціологічних теорій на грунті ціннісно-раціональних принципів інтерпретації сучасного суспільного життя.

\section{3 Актуальні проблеми сучасної соціології}

Доречно зауважимо, що у прогресуючий стан соціології вірять й економісти, прагнучи знайти відповіді на виклики сучасності, надію покладають саме на неї, а не на економічну науку.

Російський економіст Є.Балацький зазначає, що «раніше економічні феномени домінували і значною мірою формували мислення людей. Відповідно економіка була лідером серед соціальних наук, а соціологія займала підпорядкований стан. Тепер положення кардинально змінилося - національні стереотипи мислення визначають напрямок розвитку економіки. Ментальність стала первинним чинником, а економічні процеси - вторинним. Соціологія пересувається на першу позицію серед соціальних наук, а економіка відходить на задній план»

\footnotetext{
${ }^{2}$ Як влучно зазначив відомий український соціолог Є. Суїменко, сучасна соціологія скоріше переживає свій перехідний етап, ніж кризовий стан.
} 
$[2$, c. 65$]$.

Не можна не погодитися із цією думкою, оскільки саме ментальність виступає як «поєднуюча ланка між розвитком матеріальної цивілізації та духовним життям соціумів й соціальною психологією їх суб'єктів», i «втілює, - за влучним визначення С. Кримського і В. Заблоцького, - свого роду «партитуру» нормальних життєвих сценаріїв, що забезпечують відтворення етнопсихологічної та соціокультурної специфіки певних соціумів» [4, с. 369-370]. Логічно виникає наступне, виключно важливе питання: чи здатні соціологи запропонувати адекватні підходи для дослідження інтенціональності особистісної поведінки (предмет соціальної психології), ментальності національних соціумів (предмет етносоціологіï) і глобалізації суспільних відносин (предмет глобалістики)? Думаю, здатні за умов вирішення тих актуальних проблем, які властиві сучасній соціології.

Першою з них, як це не парадоксально звучить, $\epsilon$ визначення ï «вихідних постулатів», насамперед, предметного поля, без якого, як підкреслює Є. Головаха, «неможливо узгодити позиції в оцінці науковості знання, його відміни від повсякденних спостережень та життєвих стереотипів» [3, с. 7].

Другою проблемою $\epsilon$ необхідність «типологізації соціологічних теорій». На думку В. Култигіна, соціологічне знання можна було б типологізувати за таким критеріями, як: тип парадигми (описова, пояснювальна і перетворююча); рівень (теорії середнього рівня тощо); регіональна значущість (мейнстрім та соціології, що до нього не входять); масштабність (мікро-, мезо-, макросоціологія, соцієтальна соціологія, універсальні соціологічні теорії); галузь дослідження (теорії соціальних інститутів, сфер соціальної діяльності); рівень соціологічного осмислення реалій суспільства (моніторинги, полли, соціальні консалтинги, соціальне моделювання тощо); зміст (неопозитивізм, феноменологія, постмодернізм, раціональний вибір тощо) [5, с. 10-12].

Не менш важливою $€$ проблема здійснення інституціонального аналізу соціологічної теорії, тобто з'ясування функцій різних її типів, умов і мотивацій їх виникнення і функціонування» [5, с. 10-12]. Зауважимо, що останніми роками значно збільшилася кількість галузевих соціологій, предметні поля яких не завжди обгрунтовані, що породжує не тільки протистояння між різними сучасними науковими школами, але й сприяе відчуженню окремих галузей соціології. Наприклад, не припиняються суперечки стосовно соціології політики, соціології економіки, оскільки одночасно з ними існують політична соціологія, економічна соціологія. У соціологічному співтоваристві є прибічники i 
одних, і других теорій, що, в свою чергу, руйнує єдність соціологічного знання.

Не можна обійти увагою і проблему верифікації соціологічних узагальнень, висновків. Як відомо, соціологічні дослідження стали досить популярними у сфері політики. I в періоди виборчих компаній в засобах масової інформації можна зустріти абсолютно протилежні рейтинги одних і тих же політичних сил та їх лідерів. Це факт наявності так званих «кишенькових» соціологічних служб, які на замовлення своïх «спонсорів» фальсифікують результати опитувань. Вирішення цієї проблеми пов'язується із формуванням професійної етики і соціальної відповідальності соціологів за продукування неякісної соціологічної інформації, а тож підвищенням рівня підготовки молодих соціологів у вищих навчальних закладах.

I нарешті, шоста проблема - незатребуваність владними структурами фундаментальних результатів наукових досліджень. Особливо це стосується постсоціалістичних країн. Як справедливо зазначає російський соціолог Л. Москвічов, «соціологічна наука знову, як і за радянських часів, стає непричетною до вироблення принципових і стратегічних рішень, зокрема і стосовно виводу країни із системної кризи і перспектив її подальшого розвитку. На жаль, не сформульовані стратегічні загальнодержавні цінності та цілі реформ, які проводяться, що неможливо зробити без допомоги соціології» [7, с. 11-12].

\section{4 Конгруентність соціологічних дискурсів і викли- ків modernity}

Оскільки сучасне життя ставить перед соціологами все нові і нові запитання, то стає зрозумілим, що окреслені проблеми (вони властиві як вітчизняній, так і світовій соціологіï) потребують негайного вирішення, відкладати яке «на завтра» стає небезпечним. Тому соціологи різних країн намагаються відшукувати спільні точки взаєморозуміння і співпраці. Цьому сприяє Міжнародна соціологічна асоціація, яка винесла для обговорення на 16-му Всесвітньому соціологічному конгресі, тема якого - «Якість соціального існування у світі, що глобалізується» (м. Дурбан, Південно-Африканська республіка, червень 2006 р.), наступні групи проблем:

1. «Глобальні нормативності», зокрема: особливості формування глобального громадянського суспільства; соціологічний аналіз космополітизму і громадянських прав; визначення понятійного апарату му- 
льтикультуралізму як опису соціальної реальності і нормативної політичної мети.

2. «Теорія соціальної дії: нові перспективи», в рамках якої були розглянуті такі теми: людська рефлексивність та її вплив на життєдіяльність і соціальні позиції у світі; вивчення віри агентів один одному, а також її ролі у діалогічній негоціації, тобто у мові за допомогою нарративів.

3. «Епістемологія і теоретичні парадигми», в якій обговорювалися нові напрямки у філософії соціальних наук (прагматизм, теорія точки зору - standpoint theory, критична теорія); нові перспективи соціологічного знання (підходи до соціального як об'єкту науки; чи можна порівняти соціологічні пояснення реальності із поясненнями в природничих науках; концептуалізація поняття «дискурс» та його ролі у соціологічному аналізі; взаємовідносини соціології знання з новаціями соціальної філософії; роль суб'єктивності дослідника та його соціального стану у продукуванні соціологічного знання; критерії валідності соціологічної інтерпретації тощо); «новий теоретичний рух: через двадцять років»- переосмислення наукових теорій П.Бурдьє, Ю. Хабермаса, Дж. Александера, Е. Гідденса, Н. Лумана.

4. «Солідарність та їі слабкості», зокрема теоретичне осмислення насильства, його технік, технологій та наслідків; нео-дюркгеймівська теорія - переосмислення проблематики «культурного повернення» до символів та ритуалів, «утіленого Я», «колективного збудження», «нових соціальних рухів» тощо.

5. «Мистецтво і публічна сфера» - теорія і політика презентації, а точніше вивчення змісту у мистецтві та масовій культурі; нарратив у соціальній теорії- розширення розуміння, оцінки і рефлексії нараративу як ресурсу суспільствознавства.

Окрім названих, були обговорені концепти «Modernity» (сучасність), «реципрокність» (обмін дарами) та інші [1, с. 3-9].

В контексті вирішення названих проблем працюють російські та українські соціологи. Так, у березні 2006 р. в Інституті соціології РАН відбулася щорічна конференція «Соціальні реалії сучасної Росї», на якій соціальні явища розглядалися як основа для прийняття політичних рішень і здійснення політичних процесів. Провідними темами, що обговорювалися були такі: самосвідомість росіян і власність як системоутворюючі інститути суспільства (директор інституту соціології РАН М.Горшков); концепція залежності сучасного розвитку країни від минулого (В. Ядов); нова теоретична парадигма - ресурсний підхід (Н. Тихонова); оцінка потенціалу входження російського суспільства 
в інформаційну стадію розвитку (М. Черниш); соціокультурний злам російського суспільства і проблеми політичної трансформації країни (С. Патрушев); демократія перед викликами: адаптація чи зміна парадигми ( професор Ю. Красін) та інші [12, с. 15-151].

Вагомий потенціал наукових ідей мають і українські соціологи в галузі розвитку соціологічного знання (Є. Головаха, В. Тарасенко); пояснення трансформації соціальних інститутів та інституціональної структури суспільства (С. Макєєв, Н. Паніна, М.Шульга); діяльнісноструктурного аналізу саморозвитку соціальних систем (О.Куценко, Л.Бевзенко); національно-громадянських ідентичностей та толерантності (І.Мартинюк, О. Донченко); специфіки становлення ринкових відносин (В. Ворона, Є. Суїменко, В. Пилипенко, Т. Єфременко); особистісного виміру життєдіяльності (Л. Сохань, Н. Соболєва), соціокультурних змін та динаміки процесів соціальної адаптації населення (О. Злобіна, В. Тихонович); обгрунтування особливостей глобалізаційних процесів (Б. Нагорний, А. Арсеєнко) тощо.

Проте не можна не побачити, що наукові дослідження вітчизняних соціологів концентруються на пошуку детермінант і специфіки змін в локальних соціальних утвореннях, тобто на мікро- або на мезо-рівнях. Макросоціальні зміни, що пов'язані із системною кризою в України не знаходять адекватно-переконливого наукового обгрунтування. Більш того, протиріччя, що виникли між українськими соціологами в період останньої виборчої кампанії народних депутатів (березень 2006 рр.), фактично призупинили діяльність Української соціологічної асоціації, що суттєво вплинуло на розвиток вітчизняної соціологічної думки.

Як влучно підкреслив член-кореспондент РАН М. Лапін, прийшов час соціологам «піднятися над роз'єднаністю всередині свого співтовариства, щоб стимулювати конструктивний процес: формувати та систематично демонструвати усій громадськості - Пї інтелектуальним, діловим та політичним колам - соціологічне розуміння стану і шляхів подальшої еволюції російського суспільства» [11, с. 24]. I хоча вчений адресував цю пропозицію російським вченим, вона однаковою мірою може бути віднесена і до українського, і світового соціологічного співтовариства.

\section{5 Висновки}

Аналізуючи спектр питань, які обговорюють соціологи України, Росії, інших країн світу можна зробити висновок про те, що світове соціологі- 
чне співтовариство виходить на новий рівень своєї співпраці - інтеграції зусиль для оптимізації наукових досліджень, узгодження позицій щодо пошуку і визначення ціннісно-раціональних засад соціологічних обгрунтувань викликів епохи modernity.

$€$ також підстави стверджувати, що сучасна соціологія переживає свій перехідний період, який характеризується: по-перше, тим, що вона постійно демонструє свою здатність до рефлексії, яка «не дозволяє їх занадто довго перебувати у стані нерівноваги», [Ш.-О. Кюен]; по-друге, вона оперативно діагностує життя як окремого суспільства, так і людства в цілому, інформуючи владні еліти та громадськість про його стан, специфіку і тенденції розвитку, не залишаючи без уваги практично жодної больової точки як в житті окремої особистості, так і людства в цілому; по-третє, на підставі самоаналізу минулого свого стану, пропонує «три моделі створення великих теорій: пошуки всередині дисципліни, відгук на історичні злами, постійну взаємодію теорії та практики соціального світу» [9, с. 12]; і по-четверте, з'являються і дискутуються оригінальні спроби (наприклад наукові ідеї німецького соціолога X. Ессера [14] подолати мультипарадигмальність соціологічної науки і запропонувати єдине ціннісно-раціональне кредо розуміння, пояснення і обгрунтування людського буття.

\section{6 Бібліографія}

[1] Ажтуалъные проблемы теории социологии // Социс. - 2005.№ 9. - C. 3-9.

[2] Балацкий E. Экономическая наука: новые вызовы современности // Мировая экономика и международные отношения. - 2006. № 1. - С. 61-67.

[3] Головаха E. Социологическое знание: специфика, критерии научности и перспектива развития // Социология: теория, методы, маркетинг. - 2004. - № 1. - С. 5-14.

[4] Кримсъкий C., Заблоцький В. Ментальність / Філософський енциклопедичний словник / за ред. В.І.Шинкарука. - К.: Абрис. 2002. - С. 369-370.

[5] Култыгин В.П. Теоретическая социология за рубежом накануне конгресса // 2005. - №9.- С. 10-13. 
[6] Кюэн III.-A. В каком состоянии находится социология? // Cоцис. $-2006 .-$ № 8 . - С. 13-19.

[7] Москвичёв Л.Н. Этапы институционализации российской социологии // Социс. - 2006. - № 7. - С. 3-13.

[8] Осипов Г.В., Москвичёв Л.Н., Кабыща А.В. Социология.-М.: Аспект Пресс, 1996.

[9] Романовский H. Три подхода к будущему социологии // Социс. 2005. - № 3. - C. 3-12.

[10] Танчер В. Соціологічна думка України на тлі світової соціології // Соціологія: теорія, методи, маркетинг. - 1988. - № 1-2._- С. 1826.

[11] Ученыц в социологии, социология в нем. Интервью с Н.И. Лапиным // Социс. - 2006. - № 8. - С. 22-24.

[12] Халий И. Ежегодная итоговая конференция института социологии РАН // Социс. - 2006. - № 7. - С. 150-151.

[13] Штомпка П. Социология. Анализ современного общества: пер. с польск. С.М.Червонной. - М.: Логос.

[14] Esser Hartmut. Soziologie. Frankfurt a.M.-NY. Campus, 1993-2001, 7 Bde. 